\title{
Assessment of Nutrient Contents of Modified Finger Millet (Eleusine coracana) Starch
}

\author{
Bitrus Wokhe Tukura ${ }^{*}$, Florence Nkiruka Obelle, James Ukamaka Okere
}

Department of Chemistry, Faculty of Natural and Applied Sciences, Nasarawa State University, Keffi, Nigeria

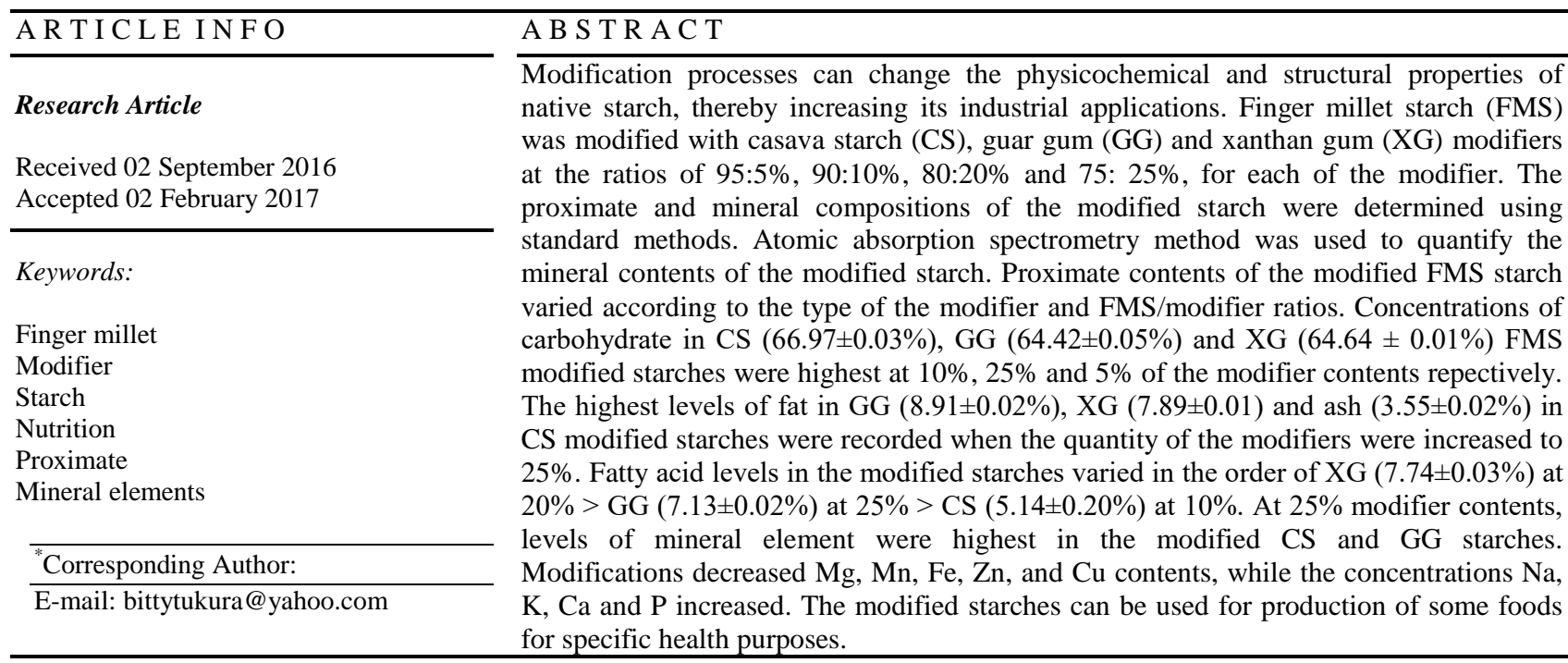

\section{Introduction}

Starch, a long chain carbohydrate, is the food of many plants that is found in potatoes, wheat, rice and other foods, and differ in appearance depending on its source (Abbas et al., 2012; Alcazar-Alay and Meireles, 2015). Starch consist of a large number of the polymers amylose and amylopectin units joined together by glycosidic bonds (Perez and Bertoft, 2010).

Native starch has limited uses in the food industry, as it produces weak-bodied, cohesive, rubbery paste when heated and undesirable gel when cooled. It also shows strong tendency towards decomposition and retrogradation, and becomes unstable with changes in temperature, $\mathrm{pH}$ and shear forces (Berski et al., 2011). Native starches are often modified to improve specific properties such as solubility, texture, adhesion and tolerance to the heating temperature used in industrial processes (Miyazaki et al., 2006; Sweedman et al., 2013; Alcazar-Alay and Meireles, 2015).

Modified starches have been produced with a variety of characteristics and applications using physical, chemical and enzymatic methods. The techniques alter the starch polymer, making it highly flexible and changing its physicochemical properties and structural attributes to increase its value for food and non-food industries (Lopez et al., 2010). Physical methods, however, involve the use of heat and moisture, while chemical modifications involve the introduction of functional groups into the starch molecule using derivatization reactions (e.g., etherification, esterification, crosslinking) or involve breakdown reactions (e.g., hydrolysis and oxidation) (Singh et al., 2007). Chemical modifications generate significant changes in retrogradation and paste properties (Lopez et al., 2010; Yousif et al., 2012; Sweedman et al., 2013; Yadav et al., 2013). Starch molecules from different origins could interact to produce attributes unique to the starch blends (Eun et al., 2009). The transformation of starch during manufacturing depends on the temperature and mixture ratio during processing (Londe-Petit et al., 2001).

Nutritional quality of food, including mineral element contents, are affected by modification processes. Minerals are inorganic substances found in body tissues and fluids, and help in the maintenance of certain physicochemical processes which are essential to life (Soetan et al., 2010). The body requires different amounts of each mineral, which depends on their age, sex, physiological state (e.g. pregnancy) and sometimes their state of health.

Minerals are involved in the formation of bones and teeth, and are components of enzyme systems which are involve in normal nerve function. Calcium, for instance, is required in large quantity for building and maintenance of bone, and normal function of nerves and muscles. Iron 
is an important component of the cytochromes that function in cellular respiration. Magnesium, copper, zinc, iron, and manganese are important co-factors found in the structure of certain enzymes and are necessary for some biochemical reactions (Zamberlin et al., 2012). Sodium and potassium, among other minerals, are important in the maintenance of osmotic balance between cells and the interstitial fluid. However, excessive intake of some minerals can upset homeostatic balance and cause toxic effects. Excess sodium intake is associated with high blood pressure and excess iron can cause liver damage (Gergely et al., 2014).

Different studies (Singh and Srivastava, 2006; Chetan and Malleshi, 2007; Shashi et al., 2007; Bwai et al., 2014) have been carried out on starches. Functional properties of FMS modified with different starches have been reported by Tukura et al. (2016). However, information on the proximate and mineral contents of the starches are scarce, therefore, the research was carried out to determine these contents in the modified FMS starches.

\section{Materials and Methods}

\section{Sample Collection}

Finger millet grain starch $(5 \mathrm{~kg})$ and $1 \mathrm{~kg}$ each of CS, GG, XG starch modifiers (Bigman, UK) were bought from a supermarket in Keffi, Nasarawa state, Nigeria, and stored for further preparation.

\section{Sample Preparation}

The method of Sira and Amaiz (2004) was adopted for the preparation of the samples. The finger millet grains (5 $\mathrm{kg}$ ) were washed with potable water and steeped for 24 hours in $0.25 \%$ sodium hydroxide solution in 10 litres of potable water. The steeped grains were washed and then ground using a Philips blender. Water (5 litres) was added to the paste and screened using $80 \mu \mathrm{m}$ mesh sieve and then centrifuged. The top brown layer was decanted and the excess sodium hydroxide was removed by washing with 5 litres of distilled water four times, until the $\mathrm{pH}$ of the starch slurry, tested with litmus paper, was almost neutral. The slurry was then dried overnight in an oven at $45^{\circ} \mathrm{C}$, cooled and stored in an airtight plastic container.

\section{Modification of Finger millet starch}

Modification was carried out by blending finger millet starch with the different modifiers (CS, XG, and GG) at the ratios of 95: 5, 90: 10, 80:20 and 75:25 $\mathrm{g}$ for each. The finger millet and modifiers were then thoroughly mixed using a Hobart mixer (Hobart legacy, HL 200, Canada), and stored in air tight plastic bags for analysis.

\section{Proximate Analysis}

Proximate analyses of the modified samples were carried out in replicate according to AOAC (2000), while carbohydrate was calculated by difference (Mathanghi and Sudha, 2012; Okibe et al., 2016):

Carbohydrate $(\%)=100-(\%$ moisture $+\%$ protein + $\%$ crude fat $+\%$ extract $+\%$ ash $)$.
Calculated fatty acid and metabolizable energy were determined using the formulae (Mathanghi and Sudha, 2012) below:

Fatty acid $=0.8 \times$ crude fat where 0.8 is the conversion factor for millets, and

Calculated as metabolizable energy $(\mathrm{Kj} / 100 \mathrm{~g})=$ $($ protein $\times 17+$ fat $\times 37+$ carbohydrate $\times 17)$.

\section{Mineral Element Analysis}

The modified and control starch samples were dryashed at $555^{\circ} \mathrm{C}$ to a constant weight. Two drops of concentrated nitric acid were added and then made up to mark with distilled water in $100 \mathrm{~cm}^{3}$ volumetric flask. The levels of mineral elements were determined using atomic absorption spectrophotometer (Perkin-Elmer Model 403, Norwalk, CT, USA). Sodium and potassium were determined using a flame photometer (Model 403, Corning, UK), with $\mathrm{NaCl}$ and $\mathrm{KCl}$ solutions as standards. Phosphorus was also determined colorimetrically with the aid of spectronic 20 (Gallen Kamp, UK) as described by Pearson (1976), using $\mathrm{KH}_{2} \mathrm{PO}_{4}$ as the standard. All chemicals used were of analytical grades.

Statistical Analysis

The data were subjected to simple statistical techniques such as mean and standard deviation (SD). Coefficient of variation (CV) and one way analysis of variance (ANOVA) was also carried out.

\section{Results and Discussion}

\section{Proximate Composition}

The proximate contents of CS modified starches are presented in Table 1. The highest levels of proteins $(9.66$ $\pm 0.03 \%)$ and fat $(6.56 \pm 0.01 \%)$ were recorded in 25 and $20 \%$ CS modified satrches respectively. Crude fiber levels decreased when the modifier content was varied from 5 to $25 \%$. The highest moisture level $(9.24 \pm 0.02 \%)$ was recorded in the $10 \% \mathrm{CS}$ modified starch, while the concentrations of ash $(3.55 \pm 0.02 \%)$ and carbohydrate $(67.23 \pm 0.06 \%)$ were highest in starch modified with $25 \%$ and $5 \%$ CS respectively. Fatty acid and metabolizable energy did not adhered to any specific trend when the modifier contents were varied. Proximate contents of the modified starches varied in decreasing order of carbohydrate $>$ moisture content $>$ protein $>$ fat $>$ crude fibere $>$ fatty acid $>$ ash.

Proximate analysis of modified GG starches (Table 2) show that the level of protein increased when the quantity of GG was increased from 5 to $20 \%$, but decreased when GG content was raised to $25 \%$. The levels of fat and crude fiber increased with increasing FMS/GG ratios. The highest levels of moisture $(8.89 \pm 0.01 \%)$ and ash $(2.88 \pm$ $0.02 \%$ ) were recorded in 10 and $20 \%$ GG modified starches respectively. $25 \%$ recorded the highest level of carbohydrate, while the lowest value $(63.13 \pm 0.02 \%)$ was obtianed in the $20 \%$ GG modified starch. Proximate composition varied in the order of carbohydrate $>$ protein $>$ fat $>$ moisture $>$ fatty acid $>$ crude fiber $>$ ash. 
Table 1 Proximate composition (\%) of CS modified finger millet starch

\begin{tabular}{l|cccccc}
\hline \multirow{2}{*}{ Parameters } & \multicolumn{5}{c}{ FMS: CS ratios (\%) } \\
\cline { 2 - 6 } & $95: 5$ & $90: 10$ & $80: 20$ & $75: 25$ & Mean \pm SD & CV $(\%)$ \\
\hline Protein (\%) & $8.61 \pm 0.02$ & $8.95 \pm 0.04$ & $8.92 \pm 0.01$ & $9.66 \pm 0.03$ & $9.04 \pm 0.44$ & 4.87 \\
Fat (\%) & $6.16 \pm 0.02$ & $6.42 \pm 0.01$ & $6.56 \pm 0.01$ & $6.18 \pm 0.02$ & $6.33 \pm 0.02$ & 3.16 \\
Crude fibre (\%) & $5.61 \pm 0.02$ & $5.25 \pm 0.04$ & $5.13 \pm 0.02$ & $4.92 \pm 0.05$ & $5.23 \pm 0.03$ & 5.74 \\
Moisture (\%) & $9.12 \pm 0.05$ & $9.24 \pm 0.02$ & $9.13 \pm 0.01$ & $9.11 \pm 0.01$ & $9.15 \pm 0.06$ & 0.66 \\
Ash (\%) & $3.25 \pm 0.01$ & $3.16 \pm 0.02$ & $3.22 \pm 0.04$ & $3.55 \pm 0.02$ & $3.30 \pm 0.17$ & 5.15 \\
Carbohydrate (\%) & $67.23 \pm 0.06$ & $66.97 \pm 0.03$ & $67.03 \pm 0.02$ & $66.58 \pm 0.01$ & $66.95 \pm 0.28$ & 0.43 \\
Fatty acid (\%) & $4.93 \pm 0.01$ & $5.14 \pm 0.02$ & $5.25 \pm 0.05$ & $4.93 \pm 0.04$ & $5.07 \pm 0.36$ & 7.10 \\
Metabolizable energy (Kj/100g) & $1585 \pm 0.02$ & $1528 \pm 0.01$ & $1534 \pm 0.03$ & $1543 \pm 0.02$ & $1543 \pm 25.87$ & 1.68 \\
\hline
\end{tabular}

Table 2 Proximate composition (\%) of GG modified finger millet starch*

\begin{tabular}{l|cccccc}
\hline \multirow{2}{*}{\multicolumn{1}{c}{ Parameters }} & \multicolumn{5}{c}{ FMS: GG ratios (\%) } \\
\cline { 2 - 6 } & $95: 5$ & $90: 10$ & $80: 20$ & $75: 25$ & Mean \pm SD & CV $(\%)$ \\
\hline Protein (\%) & $10.16 \pm 0.04$ & $10.56 \pm 0.01$ & $10.60 \pm 0.03$ & $9.61 \pm 0.01$ & $10.23 \pm 0.46$ & 4.50 \\
Fat (\%) & $8.66 \pm 0.06$ & $8.68 \pm 0.04$ & $8.88 \pm 0.02$ & $8.91 \pm 0.02$ & $8.78 \pm 0.13$ & 1.48 \\
Crude fibre (\%) & $5.66 \pm 0.01$ & $5.65 \pm 0.09$ & $5.77 \pm 0.01$ & $5.79 \pm 0.03$ & $5.72 \pm 0.07$ & 1.22 \\
Moisture (\%) & $8.56 \pm 8.88$ & $8.89 \pm 0.01$ & $8.73 \pm 0.02$ & $8.62 \pm 0.02$ & $8.70 \pm 0.14$ & 1.61 \\
Ash (\%) & $2.62 \pm 0.03$ & $2.76 \pm 0.02$ & $2.88 \pm 0.02$ & $2.37 \pm 0.01$ & $2.73 \pm 0.11$ & 4.03 \\
Carbohydrate (\%) & $64.33 \pm 0.01$ & $63.46 \pm 0.06$ & $63.13 \pm 0.02$ & $64.42 \pm 0.05$ & $63.80 \pm 0.64$ & 1.00 \\
Fatty acid (\%) & $6.93 \pm 0.04$ & $6.94 \pm 0.01$ & $5.22 \pm 0.02$ & $7.13 \pm 0.02$ & $7.03 \pm 0.10$ & 1.42 \\
Metabolizable energy (Kj/100g) & $1589 \pm 0.01$ & $1580 \pm 0.03$ & $1582 \pm 0.02$ & $1589 \pm 0.01$ & $1585 \pm 4.95$ & 0.31 \\
\hline
\end{tabular}

FMS: Finger millet starch, *Values within the same row are not significantly different $(\mathrm{P} \leq 0.05)$

Table 3 Proximate composition (\%) of XG modified finger millet starch*

\begin{tabular}{l|cccccc}
\multirow{2}{*}{\multicolumn{1}{c}{ Parameter }} & \multicolumn{5}{c}{ FMS: XG ratios (\%) } \\
\cline { 2 - 6 } & $95: 5$ & $90: 10$ & $80: 20$ & $75: 25$ & Mean \pm SD & CV $(\%)$ \\
\hline Protein (\%) & $9.61 \pm 0.01$ & $9.65 \pm 0.02$ & $9.67 \pm 0.03$ & $9.66 \pm 0.01$ & $9.65 \pm 0.02$ & 0.21 \\
Fat (\%) & $7.50 \pm 0.02$ & $7.85 \pm 0.03$ & $7.89 \pm 0.01$ & $7.89 \pm 0.04$ & $7.78 \pm 0.17$ & 2.19 \\
Crude fibre (\%) & $6.14 \pm 0.01$ & $6.22 \pm 0.01$ & $6.76 \pm 0.04$ & $6.85 \pm 0.05$ & $6.60 \pm 0.32$ & 4.85 \\
Moisture (\%) & $8.91 \pm 0.01$ & $8.09 \pm 0.05$ & $8.99 \pm 0.02$ & $9.61 \pm 0.04$ & $9.26 \pm 0.36$ & 3.89 \\
Ash (\%) & $3.20 \pm 0.02$ & $3.22 \pm 0.01$ & $3.33 \pm 0.01$ & $3.40 \pm 0.07$ & $3.29 \pm 0.08$ & 2.43 \\
Carbohydrate (\%) & $64.64 \pm 0.01$ & $63.09 \pm 0.05$ & $63.36 \pm 0.02$ & $62.57 \pm 0.01$ & $63.42 \pm 0.88$ & 1.39 \\
Fatty acid (\%) & $7.69 \pm 0.02$ & $7.72 \pm 0.01$ & $7.74 \pm 0.03$ & $7.73 \pm 0.03$ & $7.72 \pm 0.02$ & 0.38 \\
Matabolizable energy (Kj/100g) & $1540 \pm 0.01$ & $1527 \pm 0.02$ & $1533 \pm 0.03$ & $1520 \pm 0.01$ & $1530 \pm 8.44$ & 0.26 \\
\hline
\end{tabular}

FMS: Finger millet starch, *Values within the same row are not significantly different $(\mathrm{P} \leq 0.05)$

Proximate levels in XG modified FMS (Table 3) show that sodium and potassium increased as the the quantity of the modifier was increased from 5 to $20 \%$. Crude fiber level aslo increased with increasing modifier content. The highest levels of moisture $(9.61 \pm 0.04 \%)$ and ash $(3.40 \pm$ $0.07 \%$ ) were both contained in the $25 \% \mathrm{XG}$ modified starch. 5\% XG modified starch had the highest concentration $(64.64 \pm 0.01 \%)$ of carbohydrate. Fatty acid increased from the 5 to $20 \%$ XG modified satrch. The proximate levels in the modified straches were relatively lower than in the maize starch (MS) and unmodified FMS (Table 4) which were used as controls. The trend may be attributed to the modification processes. In general the proximate levels of the modified FMS were not significantly different $(\mathrm{P} \leq 0.05)$.

The protein content of the modified starches are in agreement with the values reported by Bhatt et al. (2003), but higher than the $5-8 \%$ reported by Chethan and Malleshi (2007). Moisture content is an index of food storage. The lower the moisture contents of flour, the better its shelf stability and hence the quality (Suresh and
Sumsher, 2013). FMS modifed with $25 \%$ CS and GG with the lowest moisture content will would have a longer shelf life.The fat content was within the range reported by Mahmut Sosulski (2004). The low fat content could be one of the contributing factors for the extremely good shelf life of the modified finger millet starch (Nuwamanya et al., 2011). However, the crude fiber contents were higher than the $1.3 \%$ reported by Saldivar (2003). The relatively low moisture content of the starches makes them easy to store at room temperature and less prone to colonization by organism degradation as reported for root, tuber and cereal starches (Muazu, 2011).

The ash content was higher than the $1.47-2.58 \%$ reported by Singh et al. (2007) and 3\% obtained by Seetharam (2001). Ash content represents the total mineral content in foods. High ash content signifies high mineral content which is an indication of good quality of the starches. The carbohydrate contents were higher than the values $(52.75-56.00 \%)$ reported by Gideon and Doss (2002) but lower than the $70-76 \%$ reported by Obilana 
and Manyasa (2002) for Digitaria starch. The fatty acid levels recorded for the modified starch were lower than the $8.71 \%$ reported by Glew et al. (2005). The metabolizable energy levels in this study were comparable to the $1,520 \mathrm{~kJ} / 100 \mathrm{~g}$ in brown rice and 1,503 $\mathrm{kJ} / 100 \mathrm{~g}$ in maize as reported by Hulse et al. (1980).

\section{Mineral Elements}

Mineral element compositions in starches modified with CS, GG and XG are presented in Tables 5 - 7. The levels of mineral elements in CS modified satrches (Table 5) show that the $25 \%$ CS modfid starch contained the highest levels of sodium $(1.44 \pm 0.04 \mathrm{mg} / \mathrm{g})$ and calcium $(2.45 \pm 0.05 \mathrm{mg} / \mathrm{g})$. Concentrations of potassium and magnesium increased as the levels of the CS modifier were increased from 5 to $25 \%$. The levels of phodphorus also increased as the modifier content increases, except at $10 \% \mathrm{CS}$ content. The highest concentrations of Mn $(0.50$ $\pm 0.01 \mathrm{mg} / \mathrm{g})$ and $\mathrm{Fe}(0.21 \pm 0.01 \mathrm{mg} / \mathrm{g})$ were recorded when the level of the CS modifier was increased to $20 \%$. Increase in the levels of the CS modifier lead to a corresponding increase in the concentrations of zinc and copper. The ratios of $\mathrm{Ca} / \mathrm{P}$ and $\mathrm{Na} / \mathrm{K}$ followed a similar trend.

Results for GG modified FMS starches (Table 6) show that the highest level of sodium $(1.34 \pm 0.01 \mathrm{mg} / \mathrm{g})$ and the lowest level of potassium $(1.44 \pm 0.01 \mathrm{mg} / \mathrm{g})$ were recorded in FMS modified with 20 and 10\% GG respectively. The levels of calcium increased when the guantity of GG was varied between 5 and $20 \%$. The highest level of phosphorus $(3.21 \pm 0.03 \mathrm{mg} / \mathrm{g})$ was recorded in the $25 \%$ modified starch. Magnesium and maganese levels increased with and increase in the levels of the GG modifier. 20\% GG modified starch had the highest concentrations of $\mathrm{Fe}(0.21 \pm 0.01 \mathrm{mg} / \mathrm{g}), \mathrm{Zn}(0.22$ $\pm 0.01 \mathrm{mg} / \mathrm{g})$ and $\mathrm{Cu}(0.34 \pm 0.02 \mathrm{mg} / \mathrm{g})$. Concentrations of phosphorus, calcium and magnesium were relatively the highest, while zinc was the lowest. $\mathrm{Na} / \mathrm{K}$ and $\mathrm{Ca} / \mathrm{P}$ ratios increased as the levels of GG modifier were varied from 5 to $25 \%$.

Concentrations of mineral elements in XG modified FMS (Table 7) indicated that the levels of sodium (1. $55 \pm$ $0.01 \mathrm{mg} / \mathrm{g}$ ) was highest in the $20 \% \mathrm{XG}$ modified starch, while the levels of potassium $(1.54 \pm 0.03 \mathrm{mg} / \mathrm{g})$ and phosphorus $(4.20 \pm 0.01 \mathrm{mg} / \mathrm{g})$ were highest in the $5 \%$ XG modified starch. Concentrations of calcium (3.52 \pm $0.04 \mathrm{mg} / \mathrm{g})$, magneium $(2.67 \pm 0.01 \mathrm{mg} / \mathrm{g})$ and copper $(0.25 \pm 0.06 \mathrm{mg} / \mathrm{g})$ increased when the levels of XG was increased to $25 \%$. $\mathrm{Ca} / \mathrm{P}$ and $\mathrm{Na} / \mathrm{K}$ ratios varied according to FMS/XG ratios. The levels of macrominerals varied in the order of phosphorus $>$ calcium $>$ sodium, while that of the trace minerals varied in decreasing order of zinc > manganese $>$ iron $>$ copper. The levels of macroelements and trace minerals, except for phosphorus and copper, in the modified FMS starches were lower than in the FMS but higher compared to MS, which were used as controls (Table 8).

Table 4 Proximate composition (\%)of maize starch (MS) and unmodified Finger millet starch (FMS) as controls

\begin{tabular}{l|cc}
\hline \multicolumn{1}{c|}{ Parameters } & MS & FMS \\
\hline Protein & 10.25 & 14.25 \\
Fat & 12.99 & 4.22 \\
Crude fibre & 6.67 & 6.66 \\
Moisture & 11.80 & 12.9 \\
Ash & 0.29 & 1.10 \\
Carbohydrate & 52.38 & 52.68 \\
Fatty acid & 8.21 & 11.38 \\
\hline
\end{tabular}

Table 5 Mineral contents (mg/g) in CS modified finger millet starch*

\begin{tabular}{|c|c|c|c|c|c|c|}
\hline \multirow{2}{*}{ Elements } & \multicolumn{6}{|c|}{ FMS: CS ratios (\%) } \\
\hline & $95: 5$ & $90: 10$ & $80: 20$ & $75: 25$ & Mean \pm SD & $\mathrm{CV}(\%)$ \\
\hline $\mathrm{Na}$ & $1.06 \pm 0.01$ & $1.02 \pm 0.03$ & $1.10 \pm 0.01$ & $1.44 \pm 0.04$ & $1.16 \pm 0.11$ & 9.48 \\
\hline $\mathrm{K}$ & $1.22 \pm 0.03$ & $1.30 \pm 0.02$ & $1.42 \pm 0.03$ & $1.44 \pm 0.02$ & $1.35 \pm 0.07$ & 5.18 \\
\hline $\mathrm{Ca}$ & $2.14 \pm 0.01$ & $2.12 \pm 0.04$ & $2.41 \pm 0.06$ & $2.45 \pm 0.05$ & $0.41 \pm 0.01$ & 7.49 \\
\hline $\mathrm{P}$ & $3.51 \pm 0.02$ & $3.21 \pm 0.03$ & $3.40 \pm 0.06$ & $3.15 \pm 0.01$ & $3.32 \pm 0.17$ & 5.12 \\
\hline $\mathrm{Mg}$ & $2.89 \pm 0.04$ & $3.16 \pm 0.01$ & $3.23 \pm 0.03$ & $3.33 \pm 0.02$ & $3.15 \pm 0.19$ & 6.03 \\
\hline $\mathrm{Mn}$ & $0.44 \pm 0.02$ & $0.35 \pm 0.04$ & $0.50 \pm 0.01$ & $0.35 \pm 0.03$ & $0.41 \pm 0.01$ & 17.07 \\
\hline $\mathrm{Fe}$ & $0.12 \pm 0.06$ & $0.20 \pm 0.03$ & $0.21 \pm 0.01$ & $0.19 \pm 0.05$ & $0.21 \pm 0.04$ & 19.05 \\
\hline $\mathrm{Zn}$ & $0.11 \pm 0.04$ & $0.22 \pm 0.03$ & $0.22 \pm 0.06$ & $0.23 \pm 0.03$ & $0.20 \pm 0.06$ & 30.00 \\
\hline $\mathrm{Cu}$ & $0.31 \pm 0.01$ & $0.33 \pm 0.07$ & $0.34 \pm 0.02$ & $0.34 \pm 0.04$ & $0.33 \pm 0.01$ & 3.03 \\
\hline $\mathrm{Ca} / \mathrm{P}$ & $0.61 \pm 0.03$ & $0.67 \pm 0.04$ & $0.71 \pm 0.01$ & $0.77 \pm 0.01$ & $0.69 \pm 0.07$ & 10.14 \\
\hline $\mathrm{Na} / \mathrm{K}$ & $0.86 \pm 0.04$ & $0.79 \pm 0.02$ & $0.78 \pm 0.03$ & $1.00 \pm 0.02$ & $0.86 \pm 0.09$ & 10.47 \\
\hline $\mathrm{K} /(\mathrm{Ca}+\mathrm{Mg})$ & $0.24 \pm 0.01$ & $0.25 \pm 0.03$ & $0.25 \pm 0.01$ & $0.25 \pm 0.03$ & $0.25 \pm 0.92$ & 1.57 \\
\hline
\end{tabular}

FMS: Finger millet starch, *Values within the same row are not significantly different $(\mathrm{P} \leq 0.05)$ 
Table 6 Mineral contents $(\mathrm{mg} / \mathrm{g})$ in GG modified finger millet starch*

\begin{tabular}{l|cccccc}
\hline \multirow{2}{*}{ Element } & \multicolumn{7}{c}{ FMS: GG ratios $(\%)$} & Mean \pm SD & CV $(\%)$ \\
\cline { 2 - 6 } & $95: 05$ & $90: 10$ & $80: 20$ & $75: 25$ & $1.32 \pm 0.10$ & 7.55 \\
$\mathrm{Na}$ & $1.25 \pm 0.01$ & $1.25 \pm 0.03$ & $1.34 \pm 0.01$ & $1.25 \pm 0.04$ & $1.50 \pm 0.04$ & 2.67 \\
$\mathrm{~K}$ & $1.52 \pm 0.01$ & $1.44 \pm 0.01$ & $1.50 \pm 0.04$ & $1.52 \pm 0.06$ & $3.02 \pm 0.01$ & 3.63 \\
$\mathrm{Ca}$ & $2.89 \pm 0.02$ & $2.99 \pm 0.04$ & $3.14 \pm 0.01$ & $3.10 \pm 0.02$ & $3.02 \pm 0.28$ & 9.27 \\
$\mathrm{P}$ & $3.08 \pm 0.04$ & $3.10 \pm 0.02$ & $2.70 \pm 0.05$ & $3.21 \pm 0.03$ & $2.33 \pm 0.06$ & 6.87 \\
$\mathrm{Mg}$ & $2.15 \pm 0.03$ & $2.23 \pm 0.02$ & $2.44 \pm 0.01$ & $2.49 \pm 0.01$ & $0.44 \pm 0.02$ & 4.52 \\
$\mathrm{Mn}$ & $0.41 \pm 0.02$ & $0.44 \pm 0.03$ & $0.45 \pm 0.01$ & $0.46 \pm 0.02$ & 0.02 & 4.69 \\
$\mathrm{Fe}$ & $0.41 \pm 0.04$ & $0.41 \pm 0.01$ & $0.45 \pm 0.01$ & $0.43 \pm 0.03$ & $0.43 \pm 0.02$ & 11.32 \\
$\mathrm{Zn}$ & $0.24 \pm 0.06$ & $0.24 \pm 0.03$ & $0.27 \pm 0.01$ & $0.31 \pm 0.01$ & $0.27 \pm 0.03$ & 14.56 \\
$\mathrm{Cu}$ & $0.19 \pm 0.04$ & $0.18 \pm 0.02$ & $0.24 \pm 0.01$ & $0.22 \pm 0.03$ & $0.21 \pm 0.03$ & 2.70 \\
$\mathrm{Ca} / \mathrm{P}$ & $0.93 \pm 0.06$ & $0.97 \pm 0.03$ & $1.29 \pm 0.05$ & $1.25 \pm 0.02$ & $1.11 \pm 0.03$ & 7.41 \\
$\mathrm{Na} / \mathrm{K}$ & $0.82 \pm 0.01$ & $0.47 \pm 0.03$ & $0.49 \pm 0.04$ & $0.39 \pm 0.01$ & $0.54 \pm 0.04$ & 7.14 \\
$\mathrm{~K} / \mathrm{Ca}+\mathrm{Mg})$ & $0.30 \pm 0.03$ & $0.28 \pm 0.05$ & $0.26 \pm 0.02$ & $0.27 \pm 0.01$ & $0.28 \pm 0.02$ & \\
\hline $\mathrm{FMS}: \mathrm{Finyyy}$ & &
\end{tabular}

FMS: Finger millet starch,*Values within the same row are not significantly different $(\mathrm{P} \leq 0.05)$

Table 7 Mineral contents $(\mathrm{mg} / \mathrm{g})$ in XG modified finger millet starch*

\begin{tabular}{|c|c|c|c|c|c|c|}
\hline \multirow{2}{*}{ Element } & \multicolumn{6}{|c|}{ FMS : XG ratios $(\%)$} \\
\hline & 95:05 & 90:10 & $80: 20$ & $75: 25$ & Mean \pm SD & $\mathrm{CV}(\%)$ \\
\hline $\mathrm{Na}$ & $1.45 \pm 0.01$ & $1.51 \pm 0.03$ & $1.55 \pm 0.01$ & $1.50 \pm 0.04$ & $1.52 \pm 0.01$ & 3.30 \\
\hline $\mathrm{K}$ & $1.54 \pm 0.03$ & $1.44 \pm 0.02$ & $1.45 \pm 0.06$ & $1.47 \pm 0.03$ & $1.47 \pm 0.04$ & 2.71 \\
\hline $\mathrm{Ca}$ & $3.26 \pm 0.02$ & $3.12 \pm 0.01$ & $3.46 \pm 0.01$ & $3.52 \pm 0.04$ & $3.34 \pm 0.08$ & 5.39 \\
\hline $\mathrm{P}$ & $4.20 \pm 0.01$ & $4.10 \pm 0.03$ & $3.90 \pm 0.05$ & $4.00 \pm 0.04$ & $4.05 \pm 0.12$ & 2.96 \\
\hline $\mathrm{Mg}$ & $2.55 \pm 0.02$ & $2.33 \pm 0.05$ & $2.61 \pm 0.03$ & $2.67 \pm 0.01$ & $2.54 \pm 0.05$ & 5.90 \\
\hline $\mathrm{Mn}$ & $0.32 \pm 0.01$ & $0.33 \pm 0.04$ & $0.32 \pm 0.01$ & $0.33 \pm 0.03$ & $0.33 \pm 0.09$ & 27.27 \\
\hline $\mathrm{Fe}$ & $0.24 \pm 0.02$ & $0.33 \pm 0.04$ & $0.36 \pm 0.07$ & $0.37 \pm 0.03$ & $0.33 \pm 0.06$ & 18.40 \\
\hline $\mathrm{Zn}$ & $0.36 \pm 0.04$ & $0.36 \pm 0.06$ & $0.36 \pm 0.01$ & $0.35 \pm 0.01$ & $0.36 \pm 5.06$ & 1.48 \\
\hline $\mathrm{Cu}$ & $0.20 \pm 0.01$ & $0.12 \pm 0.03$ & $0.18 \pm 0.02$ & $0.25 \pm 0.06$ & $0.16 \pm 0.05$ & 26.74 \\
\hline $\mathrm{Ca} / \mathrm{P}$ & $0.78 \pm 0.01$ & $0.76 \pm 0.02$ & $0.88 \pm 0.05$ & $0.88 \pm 0.02$ & $0.83 \pm 0.06$ & 7.23 \\
\hline $\mathrm{Na} / \mathrm{K}$ & $0.94 \pm 0.02$ & $1.00 \pm 0.04$ & $0.99 \pm 0.02$ & $0.98 \pm 0.03$ & $0.98 \pm 0.03$ & 3.06 \\
\hline $\mathrm{K} /(\mathrm{Ca}+\mathrm{Mg})$ & $0.26 \pm 0.04$ & $0.28 \pm 0.01$ & $0.26 \pm 0.03$ & $0.25 \pm 0.05$ & $0.26 \pm 0.01$ & 3.85 \\
\hline
\end{tabular}

FMS: Finger millet starch,*Values within the same row are not significantly different $(\mathrm{P} \leq 0.05)$

Table 8 Mineral levels (mg/g) in maize starch (MS) and unmodified Finger millet starch (FMS) as controls

\begin{tabular}{l|cc}
\hline \multicolumn{1}{c|}{ Element } & MS & FMS \\
\hline $\mathrm{Na}$ & 1.11 & 2.32 \\
$\mathrm{~K}$ & 1.25 & 1.9 \\
$\mathrm{Ca}$ & 1.41 & 3.16 \\
$\mathrm{P}$ & 2.49 & 2.1 \\
$\mathrm{Mg}$ & 4.12 & 4.12 \\
$\mathrm{Mn}$ & 0.32 & 0.57 \\
$\mathrm{Fe}$ & 0.11 & 0.64 \\
$\mathrm{Zn}$ & 0.13 & 0.55 \\
$\mathrm{Cu}$ & 0.29 & 0.11 \\
\hline
\end{tabular}

Consumption of mineral elements in foods, either at low or high concentration, has some health implications. Calcium deficiency can lead to ricket, osteomalacia and tooth decay (Bwai et al., 2014). Phosphorus is an important mineral for energy production and is an essential component of Adenosine Triphosphate (ATP), the energy store of the body (Shashi et al., 2007). The values in this study agreed with the result reported by Muazu et al. (2011). GG modified starch recorded the highest $\mathrm{Ca} / \mathrm{P}$ (1.11) ratio, while the values for $\mathrm{CS}$ and $\mathrm{XG}$ were below 1. GG modified starch, therefore, might be considered to be the best (Babu et al., 2007). $\mathrm{Na} / \mathrm{K}$ ratio varied in the order of $\mathrm{XG}>\mathrm{CS}>\mathrm{GG}$, with all values less than 1. Sodium/potassium ratio of 0.60 is recommended to balance blood electrolyte (Onyeraku, 2011). Values less than 1 for the modified starch indicated that the starch may have the capacity to control high blood pressure. Variations in the levels of mineral elements in the modified starches may be attributed to the different processing method used and the separation of germ and bran during milling (Alcázar-Alay and Meireles, 2015). 


\section{Conclusion}

Proximate and mineral compositions of the modified FMSvaried according to the FMS/modifier ratios and the type of modifier used. Carbohydrate content was highest in $10 \% \mathrm{CS}(66.97 \pm 0.03 \%)$ and $5 \% \mathrm{XG}(64.64 \pm 0.01 \%)$ modified FMS. Modification increased fat, crude fibre, ash and carbohydrate contents of the FMS starch. Concentration of carbohydrate varied in the order of CS > GG > XG. XG modified starch had the highest levels for $\mathrm{Na}, \mathrm{Ca}, \mathrm{P}$ and $\mathrm{Zn}$; $\mathrm{Mn}$ and $\mathrm{Fe}$ in $\mathrm{GG}$; and $\mathrm{Cu}$ in $\mathrm{CS}$. Mineral levels of the modified starches were highest when the modifier was increased to $25 \%$, except for $\mathrm{Na}$, $\mathrm{Fe}$ and $\mathrm{Cu}$. Composition of mineral elements, at all levels of the modifier, decreased on modification, except for $\mathrm{Ca}$, and $\mathrm{Cu}$. There were no significant differences $(\mathrm{P} \leq 0.05)$ in the proximate and mineral contents of the modified starch, except for carbohydrate. The modified starches may be considered as important raw materials in food industries for wide applications.

\section{References}

Abbas KA, Sahar KK. 2012. Modified starches and their usages in selected food products: A Review study. J Agric Sci. 2(2): 90 100.

Alcazar-Alay SA, Meireles MAA. 2015. Physicochemical properties, modifications, and applications of starches from different botanical sources. Food Sci Technol. 35(2): 34 - 42. http://dx.doi.org/10.1590/1678-457X.6749.

Association of Official Analytical Chemists. 2000. Official methods of analysis of AOAC International. 17th edition. P. Culliff, AOAC International Arlington, Virginia, USA 22 - 24.

Babu BV, Ramana T, Radhakrishna TM 1987. Chemical composition and protein in hybrid varieties of finger millet. Indian J Agric Sci. 57(7): 520 - 522.

Berski W, Ptaszek A, Ptaszek P, Ziobro R, Kowalski G, Grzesik M, Achremowicz B. 2011. Pasting and rheological properties of oat starch and its derivatives. Carbohydrate Polymers, 83(2): 665 671. http://dx.doi.org/10.1016/j.carbpol.2010.08.036.

Bhatt A, Singh V, Shrotria, PK, Baskheti DC. 2003. Coarse grains of Uttaranchal: Ensuring sustainable food and nutritional security. Indian Farmer's Digest, 34-38.

Bwai MD, Afolayan M, Odukomaiya D, Ikokoh P, Orishadipe A. 2014. Proximate composition, mineral and phytochemical constituents of Eleusine coracana (finger millet). Int J Advan Chem. 2(2): 171 - 174.

Chethan S, Malleshi NG. 2007. Finger millet polyphenols: characterization and their nutraceutical potential. Amer J Food Technol. 2: 582 - 592.

Conde-Petit B, Nuessli J, Arrigoni E, Escher F, Amado R. 2001. Perspectives of starch in food science. Chimia, 55(3): 201-205.

Eun JS, ZoBell DR, Wiedmeier RD. 2009. Influence of replacing barley grain with maize- based dried distillers grains with soluble on production and carcass characteristics of growing and finishing beef steers. Animal Feed Sci Technol. 152: 72 80.

Gergely A, Pappa N, Stefanovits-Banyai E, Hegedus A, Rábaic M, Szentmihalyi K. 2014. Assessment and examination of mineral elements in apricot (prunus armeniaca 1.) cultivars: A special attention to selenium and other essential elements. Eur Chem Bull. 3(8): 760-762.

Gideon G, Doss R. 2003. Nutritive evaluation of extruded and enzyme supplemented small millets in broiler chicken. Ph.D. Thesis, University of Agricultural Science, Bangalore, India. pp.201.
Glew RS, VanderJagt DJ Bosse R, Huang YS, Chuang LT, Glew RH. 2005.The nutrient content of three edible plants of the Republic of Niger. J Food Composition Anal. 18: 15-27.

Gopalan C, Sastri BVR, Balasubramanian SC, Rao BSN, Deosthale YG, Pant KC. 2000. Nutritive value of Indian foods, NIN, Hyderbad, 11-13.

Hulse JH, Lain EM, Pearson OE. 1980. Sorghum and the millets: their composition and nutritive value. Academic Press; London.

Lopez OV, Zaritzky NE, García MA. 2010. Physicochemical characterization of chemically modified corns' tarches related to rheological behavior, retrogradation and film forming capacity. J Food Engineer. 100(1): 160-168. http://dx.doi.org/10.1016/ j.jfoodeng.2010.03.041

Mahmut S, Sosulski F. 2004. Cross-linking starch at various moisture contents by phosphate substitution in an extruder. Sci Direct, 59(4): 541 - 544.

Mathanghi SK, Sudha K. 2012. Functional and phytochemical properties of finger millet (Eleusine coracana) for health. Int $\mathbf{J}$ Pharm Chem Biol Sci. 2(4): 481 - 438.

Miyazaki MR, Hung PV, Maeda T, Morita N. 2006. Recent advances in application of modified starches for bread making. Trends Food Sci Technol. 17: 591 - 599.

Muazu J, Musa H, Isah AB, Bhatia PG, Tom GM. 2011. Extraction and characterization of kaffir potato starch. A potential source of pharmaceutical raw material. J. Natural Products Plant Resources, 1(2): 41 - 49.

Nieman DC, Butterworth BE, Nieman CN. 1992. Nutrition. Rev. Edn., W.C. Brown Publisher, Dubugue, I. A.

Nuwamanya E, Baguna Y, Wembabazi E, Rubaihayo P. 2011. A comparative study of the physicochemical properties of starches from root, tuber, and cereal crops. Afri J Biotechnol. 10(56): 12018 - 12030 .

Obilana AB, Manyasa E. 2002. Millets in pseudocereals and less common cereals: Grain properties and utilization potential. Belton P. S. and Taylor, J. R. N eds. Springer-Verlag: Berlin, pp. 176-217.

Okibe FG, Jubril B, Paul ED, Shallangwa GA, Dallatu YA 2016. Effect of cooking methods on proximate and mineral composition of Fluted Pumpkin (Telfairia occidentalis) leaves. Int J Biochem Res Rev. 9(2): 1 - 7.

Oyarekua MA. 2011. Evaluation of the nutritional and microbiological status of co- fermented cereals/cowpea ' $O G I$ '. Agric Bio J North Amer. 2(1): 61 - 73.

Perez S, Bertoft E. 2010. The molecular structures of starch components and their contribution to the architecture of starch granules: a comprehensive review. Starch/Staerke, 62(8): 389 420. http://dx.doi.org/10.1002/star.201000013.

Saeid A, Hoque S, Kumar U, Das M, Muhammad N, Rahman MM, Ahmed M. 2015. Comparative studies on nutritional quality of commercial wheat flour in Bangladesh. Bangladesh J Sci Ind Res. 50(3): 181-188.

Saldivar S. 2003. Cereals: dietary importance. In B. Caballero, Trugo, L. and Finglas, P. (Eds.), Encyclopedia of Food Sciences and Nutrition, Reino Unido: Academic Press, Agosto, London. pp. $1027-1033$.

Seetharam A. 2001. Annual Report 2000-01 All India coordinated small millets improvement project, Bangalore.

Shashi BK, Sharan S, Hittalamani S, Shankar AG, Nagarathna TK. 2007. Micronutrient composition, anti-micronutirent factors, and bioaccessibility of iron in different finger millet (Eleusine coracana) genotype. Karnataka. J Agric Sci. 20(3): 583 - 585.

Singh J, Kaur L, McCarthy OJ. 2007. Factors influencing the physico-chemical, morphological, thermal, and rheological properties of some chemically modified starches for food applications. A review. Food Hydrocoloids, 21: 1 - 22.

Singh P, Srivastava S. 2006. Nutritional composition of sixteen new varieties of finger millet. J Community Mobilization Sust Develop. 1(2): 81-84.

Sira EE, Amaiz ML. 2004. A laboratory scale method for isolation of starch from pigmented sorghum. J Food Engineer. 64: 515519. 
Soetan KO, Olaiya CO, Oyewole OE. 2010.The importance of mineral elements for humans, domestic animals and plants: A review. Afric J Food Sci. 4(5): 200-222.

Suresh C, Samsher C. 2013. Assessment of functional properties of different flours. J Agric Res. 8(38): 4849-4852.

Sweedman MC, Tizzotti, MJ, Schafer C, Gilbert RG. 2013. Structure and physicochemical properties of octenyl succinic anhydride modified starches: a review. Carbohydrate Polymers, 92(1): 905 - 920. http://dx.doi.org/10.1016/j.carbpol.2012.09.040.

Tukura BW, Obelle FN. 2016. Functional characterization of blended starch. Int J Biochem Biophys Molecul Biol. 1(1): 2530http://dx.doi: 10.11648/j.ijbbmb.20160101.14
Yadav BS, Guleria P, Yadav RB. 2013. Hydrothermal modification of Indian water chestnut starch: Influence of heat-moisture treatment and annealing on the physicochemical, gelatinization, and pasting characteristics. Food Sci Technol. 53(1): 211 - 217.

Yousif EI, Gadallah MGE, Afaf MS. 2012. Physico-chemical and rheological properties of modified corn starches and its effect on noodle quality. Annals Agric Sci. 57(1): 19 - 20

Zamberlin S, Antunac N, Havranek J, Samarzija D. 2012. Mineral elements in milk and dairy products. Mljekarstvo, 62 (2): 111125 . 